Original article

\title{
Spotted fever group Rickettsia in Amblyomma dubitatum tick from the urban area of Campo Grande, Mato Grosso do Sul, Brazil
}

\author{
Jaqueline Matias ${ }^{\mathrm{a}}$, Marcos Valério Garcia ${ }^{\mathrm{b}}$, Rodrigo Casquero Cunha ${ }^{\mathrm{c}}$, \\ André de Abreu Rangel Aguirre ${ }^{\mathrm{a}}$, Jacqueline Cavalvante Barros ${ }^{\mathrm{b}}$, \\ Bárbara Guimarães Csordas ${ }^{\mathrm{a}}$, Renato Andreotti ${ }^{\mathrm{b}, *}$ \\ a Programa de Pós-graduação em Doenças Infecciosas e Parasitárias, Faculdade de Medicina, Universidade Federal de Mato Grosso do Sul, \\ Campo Grande, MS, Brazil \\ ${ }^{\mathrm{b}}$ Embrapa Beef Cattle, Av. Radio Maia 830, Vila Popular, Campo Grande, MS, Brazil \\ c Programa de Pós-Graduação em Biotecnologia, Universidade Federal de Pelotas, Bolsista PNPD/CAPES, Brazil
}

\section{A R T I C L E I N F O}

\section{Article history:}

Received 11 June 2014

Received in revised form 6 October 2014

Accepted 13 October 2014

Available online 8 November 2014

\section{Keywords:}

Spotted fever group

Tick

Amblyomma dubitatum

Zoonosis

Urban área

Campo Grande

\begin{abstract}
A B S T R A C T
Rickettsia infection of each tick was evaluated by the hemolymph test and polymerase chain reaction (PCR) targeting gltA and ompA genes. All hemolymph tests were negative and PCR of one A. dubitatum detected both Rickettsia genes. Sequence of ompA exhibited a $99 \%$ identity with Rickettsia parkeri and $R$. africae and a $98 \%$ identity with $R$. sibirica. Rickettsia of the spotted fever group in $A$. dubitatum is described for the first time in an urban area within the municipality of Campo Grande in the state of Mato Grosso do Sul (MS), Brazil. This finding reinforces the importance of more detailed studies to determine the role of $A$. dubitatum in the transmission of spotted fever agents.
\end{abstract}

(C) 2014 Elsevier GmbH. All rights reserved.

\section{Introduction}

Rickettsioses constitute a group of diseases caused by bacteria of the genus Rickettsia, which are Gram-negative, obligate intracellular bacteria that are associated with invertebrate vectors (Raoult and Roux, 1997). Human cases of infection by bacteria of this genus have been described in world widely (Angerami et al., 2012; Kelly et al., 1992; Demma et al., 2006).

In Brazil, the disease caused by the bacteria Rickettsia rickettsii is known as Brazilian Spotted Fever (BSF) (Labruna, 2009). The southeast region of Brazil is distinguished by a greater incidence of BSF cases and number of deaths (Del Fiol et al., 2010). The high mortality rate recorded in Brazil is primarily caused by the difficulty of obtaining a rapid and accurate diagnosis when patients affected with this disease present with initial nonspecific symptoms (Spolidorio et al., 2010).

Currently, the main vectors of $R$. rickettsii for humans in Brazil are the tick species Amblyomma cajennense and A. aureolatum

\footnotetext{
* Corresponding author at: Embrapa Beef Cattle, Avenida Rádio Maia, N 830, Zona Rural, Campo Grande, CEP 79106-550 MS, Brazil. Tel.: +55 673368 2173; fax: +55 673682150 .

E-mail address: renato.andreotti@embrapa.br (R. Andreotti).
}

(Ogrzewalska et al., 2012; Guedes et al., 2011). However, R. rickettsii and other bacteria from the spotted fever group (SFG) have been found in different species of ticks (Ogrzewalska et al., 2013; Labruna et al., 2011; Almeida et al., 2013a,b).

The capybara (Hydrochoerus hydrochaeris) is the primary host of A. dubitatum (Nava et al., 2010), and it is also among the main hosts of the adult stage of $A$. cajennense (Pacheco et al., 2007). This rodent is involved in maintaining $R$. rickettsii in nature because of the capybara's ability to act as an amplifying host of $R$. rickettsii (Souza et al., 2009).

Despite the lack of knowledge of the role of $A$. dubitatum in the transmission of BSF, there is speculation regarding its possible involvement in maintaining the enzootic cycle of $R$. rickettsii in nature (Labruna et al., 2004). In this study, the presence of Rickettsia species from the SFG in free-living ticks from urban areas is investigated, and we describe the first report of a natural infection of Rickettia sp. in A. dubitatum in the state of Mato Grosso do Sul.

\section{Materials and methods}

Study site

This study was conducted between March 2013 and February 2014 in the municipality of Campo Grande in the state of Mato 


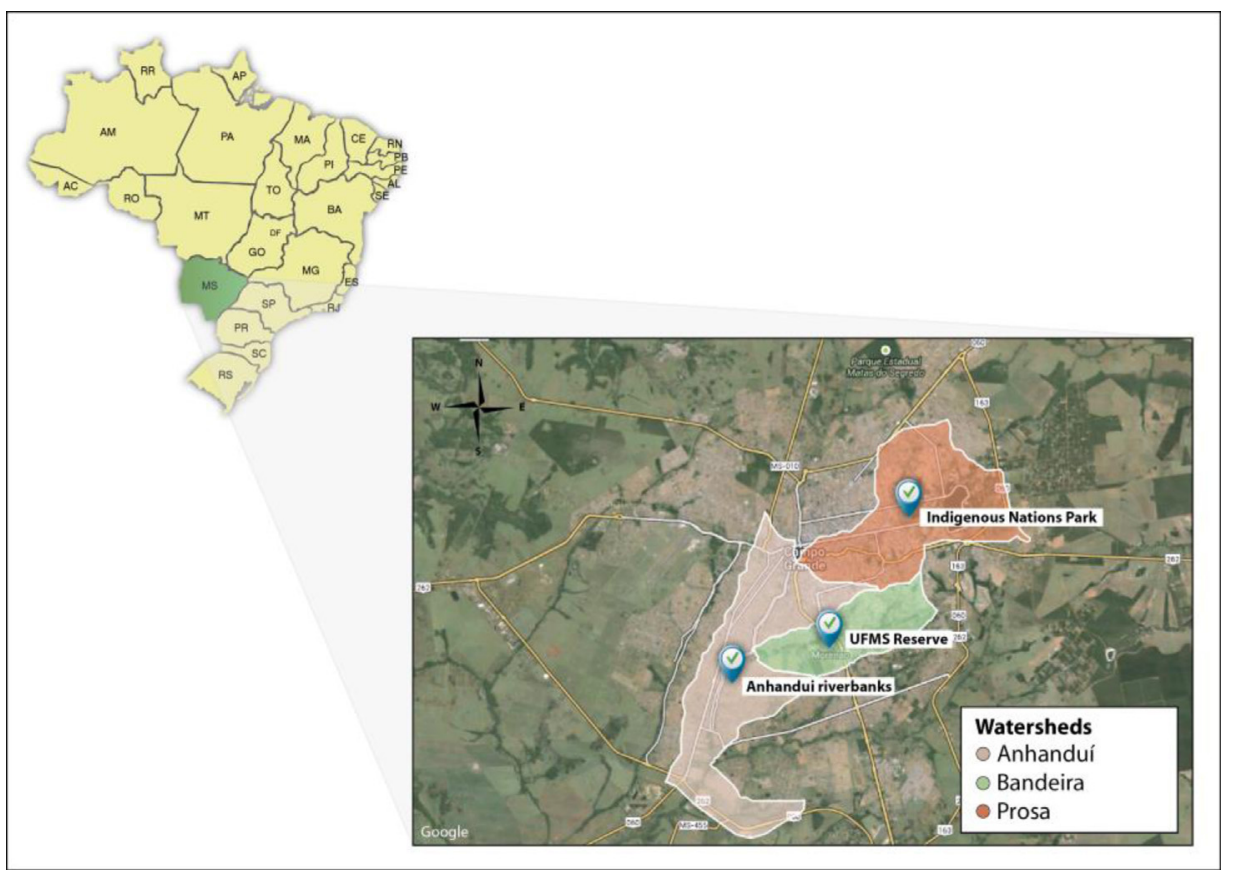

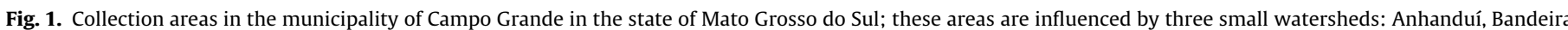
and Prosa.

Grosso do Sul, Brazil. This municipality is located in the mid-west region of the state, and it contains a population of approximately 832,352 inhabitants ( $32.1 \%$ of the state population) and has an area of $8092.95 \mathrm{~km}^{2}$. The total urban area is $154.45 \mathrm{~km}^{2}$, and it is located at an average altitude of $592 \mathrm{~m}$ above sea level (IBGE, 2010).

This municipality is included in the Cerrado biome and contains 33 named streams within the urban perimeter that are distributed within ten small watersheds (data from the Municipal Town Hall, available at: http://www.pmcg.ms.gov.br/meioambiente/).

The ticks were collected in three areas [the Indigenous Nations (Nações Indígenas, $20^{\circ} 27^{\prime} 11.2^{\prime \prime} \mathrm{S} 54^{\circ} 34^{\prime} 00.8^{\prime \prime} \mathrm{W}$ ) Park, natural reserve of the Federal University of Mato Grosso do Sul (Universidade Federal de Mato Grosso do Sul - UFMS, $20^{\circ} 29^{\prime} 57.4^{\prime \prime} \mathrm{S}$ $\left.54^{\circ} 36^{\prime} 54.8^{\prime \prime} \mathrm{W}\right)$ and along the Anhanduí riverbanks (20 30'32.8” $\mathrm{S}$ $54^{\circ} 39^{\prime} 01.9^{\prime \prime} \mathrm{W}$ ) as part of an ongoing study of the tick fauna of MS. All of the areas are inhabited by capybaras and are considered rest areas for these populations.

\section{Tick collection and identification}

Free-living ticks were captured using $\mathrm{CO}_{2}$ traps as described by Oliveira et al. (2000) taken alive to the tick biology laboratory of Embrapa Beef Cattle and identified according to Barros-Battesti et al. (2006). For the direct detection of Rickettsia, each tick was subjected to the hemolymph test (Burgdorfer, 1970) and stained as described by Giménez (1969). Ticks were stored at $-80^{\circ} \mathrm{C}$ until DNA extraction.

\section{DNA extraction and $P C R$}

The adult ticks were analized individually and the nymphs were analized in group of ten. DNA was extracted from the ticks using the DNAzol Reagent commercial kit Invitrogen (Carlsbard, USA) and subsequently subjected to a polymerase chain reaction (PCR). The oligonucleotides CS-78 and CS-323 were used to amplify a fragment of 401 base pairs (bp) of the citrate synthase gene ( $\mathrm{gltA}$ ), which is present in the rickettsial species (Labruna et al., 2004). The PCR was standardized to a final volume of $25 \mu \mathrm{l}$, with DNA concentrations between 50 and $250 \mathrm{ng} / \mu \mathrm{l}$ and an $A_{260 \mathrm{~nm}} / A_{280 \mathrm{~nm}}$ ratio $\geq 1.8$.

The positive DNA samples were tested by means of another PCR using the oligonucleotides Rr190.70p and Rr190.602n, which amplify a 530-bp fragment of the ompA gene (190-kDa protein) that is only present in the Rickettsia species from the SFG (Regnery et al. 1991).

The amplified product of the PCR-ompA was purified using the Purelink Kit (Invitrogen) and subsequently cloned and sequenced. Sequencing was performed using the Sanger method (Sanger et al., 1977) in an ABI 3130 Genetic Analyzer (Applied Biosystems). The

Table 1

Tick numbers collected and analyzed by PCR for rickettsial infection in the urban area of Campo Grande, Mato Grosso do Sul state, Brazil, $2013-2014$.

\begin{tabular}{|c|c|c|c|c|c|}
\hline \multirow[t]{2}{*}{ Locality } & \multirow[t]{2}{*}{ Geographic coordinates } & \multicolumn{4}{|l|}{ Ticks } \\
\hline & & Species & Tested $(n)$ & Infected $n(\%)$ & Rickettsia species \\
\hline \multirow{3}{*}{ UFMS Reserve } & \multirow{3}{*}{$\begin{array}{l}20^{\circ} 29^{\prime} 57.4^{\prime \prime} \mathrm{S} \\
54^{\circ} 36^{\prime} 54.8^{\prime \prime} \mathrm{W}\end{array}$} & Amblyomma cajennense & 785 & 0 & - \\
\hline & & Amblyomma dubitatum & 74 & 0 & - \\
\hline & & Amblyomma spp. nymphs & 222 & 0 & - \\
\hline Anhandui riverbanks & $20^{\circ} 30^{\prime} 32.8^{\prime \prime} \mathrm{S} 54^{\circ} 39^{\prime} 01.9^{\prime \prime} \mathrm{W}$ & Amblyomma dubitatum & 10 & $1(10)$ & Rickettsia sp. \\
\hline Indigenous Nations & $20^{\circ} 27^{\prime} 11.2^{\prime \prime} \mathrm{S}$ & Amblyomma dubitatum & 3 & 0 & - \\
\hline Park & $54^{\circ} 34^{\prime} 00.8^{\prime \prime} \mathrm{W}$ & Amblyomma spp. nymphs & 3 & 0 & - \\
\hline Total & & & 1097 & 0.09 & \\
\hline
\end{tabular}




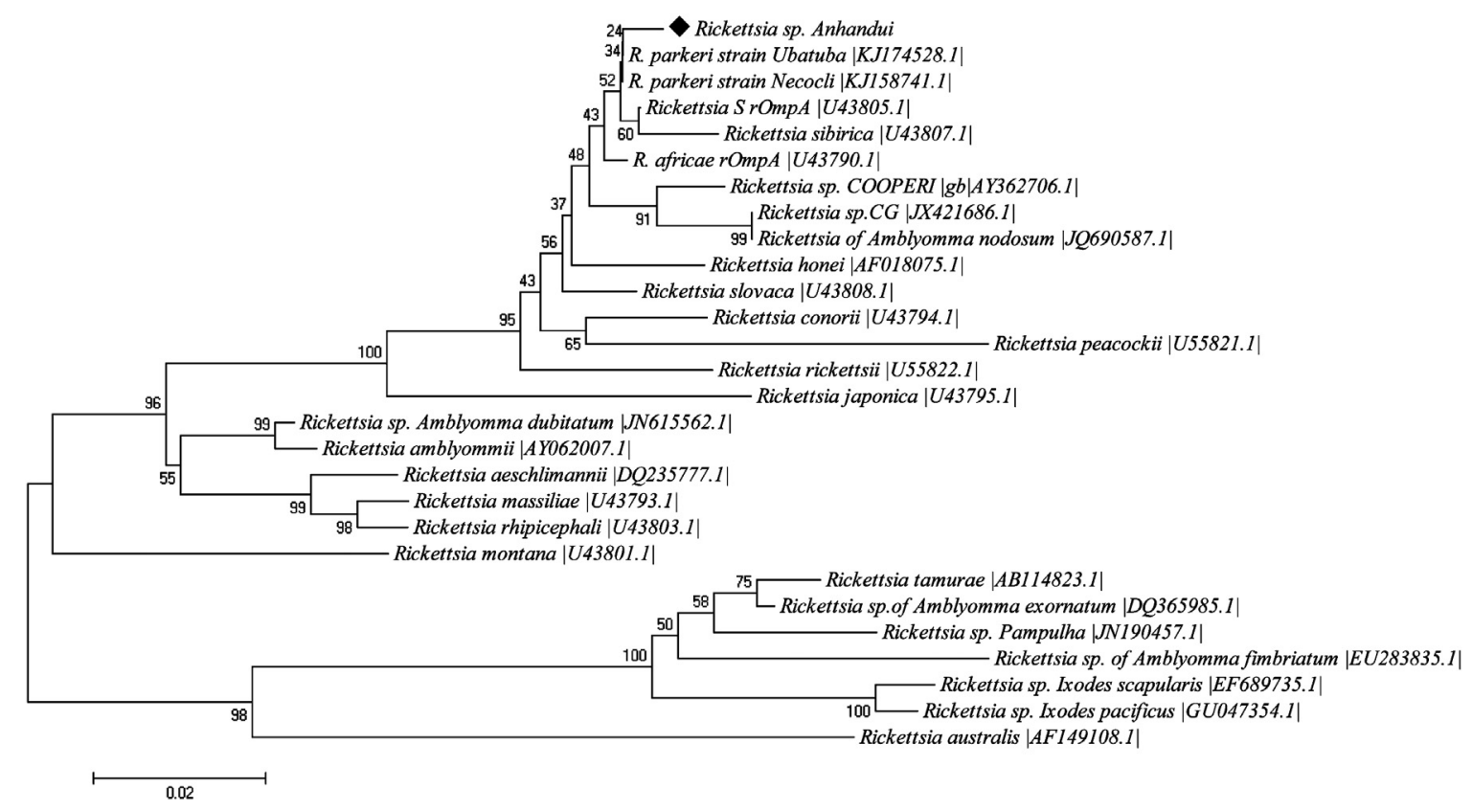

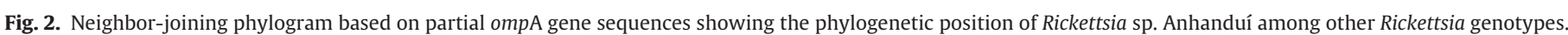

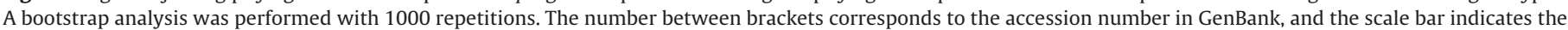
nucleotide substitutions per site.

sample was sequenced, and the consensus sequence was obtained using the BioEdit program (Hall, 1999). The obtained sequences were compared to the data from GenBank. A BLASTn search (http://blast.ncbi.nlm.nih.gov/Blast.cgi.) was performed to determine the sequence identity (Altschul et al., 1990), and phylogenetic analyses were conducted using the program MEGA version 3.1 (Kumar et al., 2004).

\section{Results and discussion}

A total of 1097 ticks were collected in the three areas during the study period. Only two tick species, Amblyomma cajennense and Amblyomma dubitatum, were identified, and they were present in the proportion of 9:1, respectively (Table 1 ).

The species $A$. cajennense recently underwent a taxonomic reevaluation that resulted in the revalidation of three species and the description and definition of three new species (Nava et al., 2014). The geographic distribution of the six species of the A. cajennense complex proposed by Nava et al. (2014) identified the presence of A. sculptum and A. cajennense s.s. to date in Brazil. Amblyomma sculptum is the current specie in this mid-west region, mentioned by the above authors, where this research was realized.

Amblyomma dubitatum is a South American tick species (Guglielmone et al., 2003). In Brazil, the geographic distribution of A. dubitatum is concentrated in the provinces of Cerrado, Atlantic Forest, Parana Forest and Araucaria angustifolia Forest (Nava et al., 2010). The distribution of Amblyomma dubitatum is less restricted than that of its main host, the capybara, which suggests different responses to environmental variables (Nava et al., 2010). Nevertheless, the three studied urban areas that are influenced by three small watersheds (Fig. 1) are inhabited by capybaras and Amblyomma dubitatum.

A hemolymph test was performed on the male and female adult ticks, and all of the samples were negative, which is a similar result to that of other authors (Almeida et al., 2013b; Veronez et al., 2010). The difficulty in detecting rickettsias is observed even in endemic areas of spotted fever (Estrada et al., 2006), indicating that a negative result should be analyzed with caution.
PCR of one sample of A. dubitatum, collected on the Anhanduí riverbank, detected Rickettia genes. Amplification of the ompA PCR product placed it in the spotted fever group.

The product generated from the PCR-ompA was cloned and sequenced, and after alignment, the generated nucleotide sequences revealed a $99 \%$ (489/494) identity with the ompA sequences that corresponded to the $R$. parkeri of the Ubatuba (KJ174528) and Necocli (KJ158741) strains found in A. ovale, 99\% (488/494) identity with Rickettia S rOmpA(U43805) of R. sanguineus, 99\% (487/494) identity with $R$. africae (U43790) found in A. variegatum and a $98 \%(484 / 494)$ identity with $R$. sibirica (U43807) found in Dermacentor nuttali (Fig. 2). The Brazilian SFG isolate identified in this study was designated as Rickettsia spp. Anhaduí strain, and the partial sequence of the ompA gene was deposited in GenBank with the accession number KJ944582.

The presence of a species of Rickettsia from the spotted fever group, designated in this study as the Anhanduí strain, in A. dubitatum is reported for the first time in an urban area of the municipality of Campo Grande in the state of Mato Grosso do Sul. The first studies conducted in this state were performed by Ogrzewalska et al. (2013), who detected for the first time the presence of the Rickettsia parkeri-like agent that infected Amblyomma calcaratum nymphs in birds, and by Almeida et al. (2013a, 2013b), who detected the presence of Rickettia spp. in Amblyomma nodosum in anteaters and $R$. rickettisi in $R$. sanguineus in dogs of the urban area. All of these results reveal the involvement of different species of ticks in the circulation of SFG agents in different areas of the state of Mato Grosso do Sul.

The possible involvement of $A$. dubitatum as an enzootic vector of the Rickettsia species deserves greater attention because a coinfestation of $H$. hydrochaeris with $A$. dubitatum and A. cajennense is usually reported (Pacheco et al., 2007; Souza et al., 2009). Moreover, A. dubitatum may eventually bite humans (Labruna et al., 2007), and the bite can have induce at different periods of the disease transmission; this observation is based on the work of Guedes and Leite (2008), who noted a differentiated seasonal pattern for the free-living stages of $A$. dubitatum compared to the $A$. cajennense population in an endemic area of spotted fever. 
Rickettsia herein described exhibited more than a 98\% identity with $R$. parkeri, $R$. africae and $R$. sibirica. Walker and Ismail (2008) and Pacheco et al. (2012) suggested that these three species constitute a single Rickettsia species. These species and closely related Rickettsia are known to cause human rickettsiosis with milder symptoms in several countries including Brazil (Paddock et al., 2004; Parola et al., 2005; Spolidorio et al., 2010, Silva et al., 2011).

\section{Conclusion}

In conclusion, Rickettia sp. was found to infect $A$. dubitatum under natural conditions in the urban area of Campo Grande, MS, Brazil. This tick species can eventually bite humans, which reinforces the importance of more detailed studies to determine its actual involvement in the transmission of spotted fever agents.

\section{Acknowledgments}

This study was supported by CNPq (National Council for Scientific and Technological Development), CAPES (the Brazilian Federal Agency for the Support and Evaluation of Graduate Education), Embrapa Beef Cattle.

\section{References}

Almeida, R.F.C., Garcia, M.V., Cunha, R.C., Matias, J., Labruna, M.B., Andreotti, R., 2013a. The first report of Rickettsia spp. in Amblyomma nodosum in the state of Mato Grosso do Sul, Brazil. Ticks Tick Borne Dis. 4, 156-159.

Almeida, R.F., Garcia, M.V., Cunha, R.C., Matias, J., Silva, E.A., Matos, M.F.C., Andreotti, R., 2013b. Ixodid fauna and zoonotic agents in ticks from dogs: first report of Rickettsia rickettsii in Rhipicephalus sanguineus in the state of Mato Grosso do Sul, mid-western Brazil. Exp. Appl. Acarol. 60, 63-72.

Angerami, R.N., Câmara, M., Pacola, M.R., Rezende, R.C., Duarte, R.M., Nascimento, E.M.M., Colombo, S., Santos, F.C.P., Leite, R.M., Katz, G., Silva, L.J., 2012. Features of Brazilian spotted fever in two different endemic areas in Brazil. Ticks Tick Borne Dis. 3, 345-347.

Altschul, S.F., Gish, W., Miller, W., Myers, E.W., Lipman, D.J., 1990. Basic local alignment search tool. J. Mol. Biol. 215, 403-410.

Barros-Battesti, D.M., Arzua, M., Bechara, G.H., 2006. Carrapatos de importância médico-veterinária da Região Neotropical: Um guia ilustrado para identificação de espécies $[[\mathrm{n}]]$ Ticks of medical-veterinary importance in the Neotropical Region: an illustrated guide for species identification, vol. 1. Butantan, São Paulo, pp. 223.

Burgdorfer, W., 1970. Hemolymph test. A technique for detection of Rickettsiae in ticks. Am. J. Trop. Med. Hyg. 19 (6), 1010-1014, PMid: 4992724.

Del Fiol, F.S., Junqueira, F.M., Rocha, M.C.P., Toledo, M.I., Filho, S.B., 2010. Febre maculosa no Brasil[[n]]Spotted fever in Brazil. Rev. Panam. Salud Publica 27, 461-466.

Demma, L.J., Traeger, M., Blau, D., Gordon, R., Johnson, B., Dickson, J., Ethelbah, R., Piontkowski, S., Levy, C., Nicholson, W.L., Duncan, C., Heath, K., Cheek, J., Swerdlow, D.L., McQuiston, J.H., 2006. Serologic evidence for exposure to Rickettsia rickettsii in eastern Arizona and recent emergence of Rocky Mountain spotted fever in this region. Vector Borne Zoonotic Dis. 6, 423-429.

Estrada, D.A., Schumaker, T.T.S., Souza, C.E., Rodrigues Neto, E.J., Linhares, A.X., 2006. Deteccão de riquétsias em carrapatos do gênero Amblyomma (Acari: Ixodidae) coletados em parque urbano do município de Campinas, SP[[n]]Rickettsiae detection in Amblyomma ticks (Acari: Ixodidae) collected in the urban area of Campinas city, SP. Rev. Soc. Bras. Med. Trop. 39, 68-71.

Giménez, D.F., 1969. Staining rickettsiae in yolk-sac cultures. Stain. Technol. 39, $135-140$.

Guedes, E., Leite, R.C., 2008. Dinâmica sazonal de estádios de vida livre de Amblyomma cajennense e Amblyomma dubitatum (Acari: ixodidae) numa área endêmica para febre maculosa, na região de Coronel Pacheco, Minas Gerais[[n]]Seasonal dynamics of the free-living stages of Amblyomma cajennense and Amblyomma dubitatum (Acari: ixodidae) in an endemic area of spotted fever in the region of Coronel Pacheco, Minas Gerais. Rev. Bras. Parasitol. Vet. 17 $78-82$.

Guedes, E., Leite, R.C., Pacheco, R.C., Silveira, I., Labruna, M.B., 2011. Rickettsia species infecting Amblyomma ticks from an area endemic for Brazilian spotted fever in Brazil. Rev. Bras. Parasitol. Vet. 20, 308-311.
Guglielmone, A.A., Estrada Peña, A., Keirans, J.E., Robbins, R.G., 2003. Ticks (Acari: Ixodida) of the Neotropical Zoogeographic Region. Special Publication, International Consortium on Ticks and Tick-Borne Diseases (ICTTD-2), Atalanta, Houten.

Hall, T.A., 1999. BioEdit: a user-friendly biological sequence alignment editor and analysis program for Windows 95/98/NT. Nucleic Acids Symp. Ser. 41, 95-98.

IBGE, 2010. Instituto Brasileiro de Geografia e Estatística. Brazilian Institute of Geography and Statistics, Available at: http://www.cidades.ibge. gov.br/xtras/home.php (accessed March 2014).

Kelly, P., Matthewman, L., Beati, L., Raoult, D., Mason, P., Dreary, M., Makombe, R. 1992. African tick bite fever: a new spotted fever group rickettsiosis under an old name. Lancet 340, 982-983.

Kumar, S., Tamura, K., Nei, M., 2004. MEGA3: integrated software for molecular evolutionary genetics analysis and sequence alignment. Brief. Bioinform. 5 150-163.

Labruna, M.B., Whitworth, T., Horta, M.C., Bouyer, D.H., McBride, J.W., Pinter, A., Popov, V., Gennari, S.M., Walker, D.H., 2004. Rickettsia species infecting Amblyomma cooperi ticks from an area in the State of São Paulo, Brazil, where Brazilian spotted fever is endemic. J. Clin. Microbiol. 42, 90-98.

Labruna, M.B., Pacheco, R.C., Ataliba, A.C., Szabó, M.P.J., 2007. Human parasitism by the capybara tick, Amblyomma dubitatum (Acari: Ixodidae) in Brazil. Entomol. News 118, 77-80.

Labruna, M.B., 2009. Ecology of Rickettsia in South America. Ann. N.Y. Acad. Sci. 1166 $156-166$.

Labruna, M.B., Salim Matar, V., Nava, S., Bermudes, S., Venzal, J.M., Abarca, K., Romero, L., de Souza, R., Oteo, J., Zavala-Castro, J., 2011. Rickettsioses in Latin America, Caribbean, Spain and Portugal. Rev. MVZ Cordoba 16, 2435-2457.

Nava, S., Venzal, J.M., Labruna, M.B., Mastropaolo, M., Gonzáles, E.M., Mangold, A.J., Guglielmone, A.A., 2010. Hosts, distribution and genetic divergence (16S rDNA) of Amblyomma dubitatum (Acari, Ixodidae). Exp. Appl. Acarol. 51, 335-351.

Nava, S., Beati, L., Labruna, M.B., Cáceres, A.G., Mangold, A.J., Guglielmone, A.A. 2014. Reassessment of the taxonomic status of Amblyomma cajennense with the description of three new species, Amblyomma tonelliae n. sp., Amblyomma interandinum n. sp. and Amblyomma patinoi n. sp., and reinstatement of Amblyomma mixtum, and Amblyomma sculptum (Ixodida, Ixodidae). Ticks Tick Borne Dis. 5, 252-276.

Ogrzewalska, M., Saraiva, D.G., Moraes-Filho, J., Martins, T.F., Costa, F.B., Pinter, A. Labruna, M.B., 2012. Epidemiology of Brazilian spotted fever in the Atlantic Forest, state of São Paulo, Brazil. Parasitology 139, 1283-1300.

Ogrzewalska, M., Martins, T., Capek, M., Literak, I., Labruna, M.B., 2013. A Rickettsic parkeri-like agent infecting Amblyomma calcaratum nymphs from wild birds in Mato Grosso do Sul, Brazil. Ticks Tick Borne Dis. 4, 145-147.

Oliveira, P.R., Borges, L.M., Lopes, C.M., Leite, R.C., 2000. Population dynamics of the free-living stages of Amblyomma cajennense (Fabricius, 1787) (Acari: Ixodidae) on pastures of Pedro Leopoldo Minas Gerais State, Brazil. Vet. Parasitol. 92, 295-301.

Pacheco, R.C., Arzua, M., Nieri-Bastos, F.A., Moraes-Filho, J., Marcili, A., Richtzenhain, L.J., Barros-Battesti, D.M., Labruna, M.B., 2012. Rickettsial infection in ticks (Acari: Ixodidae) collected on birds in southern Brazil. J. Med. Entomol. 49, $710-716$.

Paddock, C.D., Sumner, J.W., Comer, J.A., Zaki, S.R., Goldsmith, C.S., Goddard, J., McLellan, S.L., Tamminga, C.L., Oh, C.A., 2004. Rickettsia parkeri: a newly recognized cause of spotted fever rickettsiosis in the United States. Clin. Infect. Dis. 38 805-811.

Parola, P., Davoust, B., Raoult, D., 2005. Tick- and flea-borne rickettsial emerging zoonoses. Vet. Res. 36, 469-492.

Pacheco, R.C., Horta, M.C., Moraes-Filho, J., Ataliba, A.C., Pinter, A., Labruna, M.B. 2007. Rickettsial infection in capybaras (Hydrochoerus hydrochaeris) from São Paulo, Brazil: serological evidence for infection by Rickettsia bellii and Rickettsia parkeri. Biomedica 27, 364-371.

Raoult, D., Roux, V., 1997. Rickettsioses as paradigms of new or emerging infectious diseases. Clin. Microbiol. Rev. 10, 694-719.

Regnery, R.L., Spruill, C.L., Plikaytis, B.D., 1991. Genotypic identification of rickettsiae and estimation of intraspecies sequence divergence for portions of two rickettsial genes. J. Bacteriol. 173, 1576-1589.

Sanger, F., Nicklen, S., Coulson, A.R., 1977. DNA sequencing with chain-terminating inhibitors. Proc. Natl. Acad. Sci. U.S.A. 74, 5463-5467.

Silva, N., Eremeeva, M.E., Rozental, T., Ribeiro, G.S., Paddock, C.D., Ramos, E.A., Favacho, A.R., Reis, M.G., Dasch, G.A., Lemos, E.R., Ko, A.I., 2011. Eschar-associated spotted fever rickettsiosis, Bahia, Brazil. Emerg. Infect. Dis. 17, 275-278.

Souza, C.E., Moraes-Filho, J., Ogrezewalska, M., Uchoa, F.C., Horta, M.C., Souza, S.S.L. Borba, R.C.M., Labruna, M.B., 2009. Experimental infection of capybaras Hydrochoerus hydrochaeris by Rickettsia rickettsii and evaluation of the transmission of the infection to ticks Amblyomma cajennense. Vet. Parasitol. 161, 116-121.

Spolidorio, M.G., Labruna, M.B., Mantovani, E., Brandao, P.E., Richtzenhain, L.J., Yoshinari, N.H., 2010. Novel spotted fever group rickettsiosis, Brazil. Emerg. Infect. Dis. $16,521-523$.

Veronez, V.A., Freitas, B.Z., Olegário, M.M., Carvalho, W.M., Pascoli, G.V., Thorga, K. Garcia, M.V., Szabó, M.P., 2010. Ticks (Acari: Ixodidae) within various phytophysiognomies of a Cerrado reserve in Uberlândia, Minas Gerais, Brazil. Exp. Appl. Acarol. 50, 169-179.

Walker, D.H., Ismail, N., 2008. Emerging and re-emerging rickettsioses: endothelial cell infection and early disease events. Nat. Rev. Microbiol. 6, 375-386. 